\title{
The International Association of Geochemistry and Cosmochemistry
}

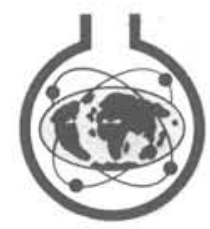

\section{by Brian Hitchon}

International activities in geochemistry were once coordinated in association with the International Union of Pure and Applied Chemistry (IUPAC) and the International Union of Geodesy and Geophysies (IUGG). Now, however, this is the role of the International Association of Geochemistry and Cosmochemistry (IAGC), founded in 1967. In this second profile of IUGS affiliates, the background structure and program of this very dynamic Association is described by its current Secretary. (Ed.)

\section{Historical Background}

The origins of IAGC may be traced back to 1951, when IUPAC approved a proposal for the establishment of a commission for geochemistry in the section on Inorganic Chemistry, with Paul Niggli (Switzerland) as Chairman and M. Fleischer (U.S.A.) as Vice-Chairman. Fleischer suceeeded to the position of Chairman after the death of Niggli
The position of the commission in the structure of IUPAC was that of a relatively small body within the large section on Inorganic Chemistry. This did not allow sufficient independence, and explorations were undertaken to examine the possibility of organizing an independent Union of Geochemistry, or of meeting with the International Geological Congress (IGC), which had had a section on geochemistry at its meetings since 1948. Other possibilities included the development of a liaison with IUGG where a separate geochemical section might be established, and a possible transformation into an International Union of Geophysies and Geochemistry.

To discuss these various viewpoints, IUGG provided a forum at their Twelfth General Assembly at Helsinki, 1960. A.P. Vinogradov (U.S.S.R., then Chairman of the IUPAC commission) expressed the opinion that geochemistry is a discipline of chemistry and that the relations established with IUPAC
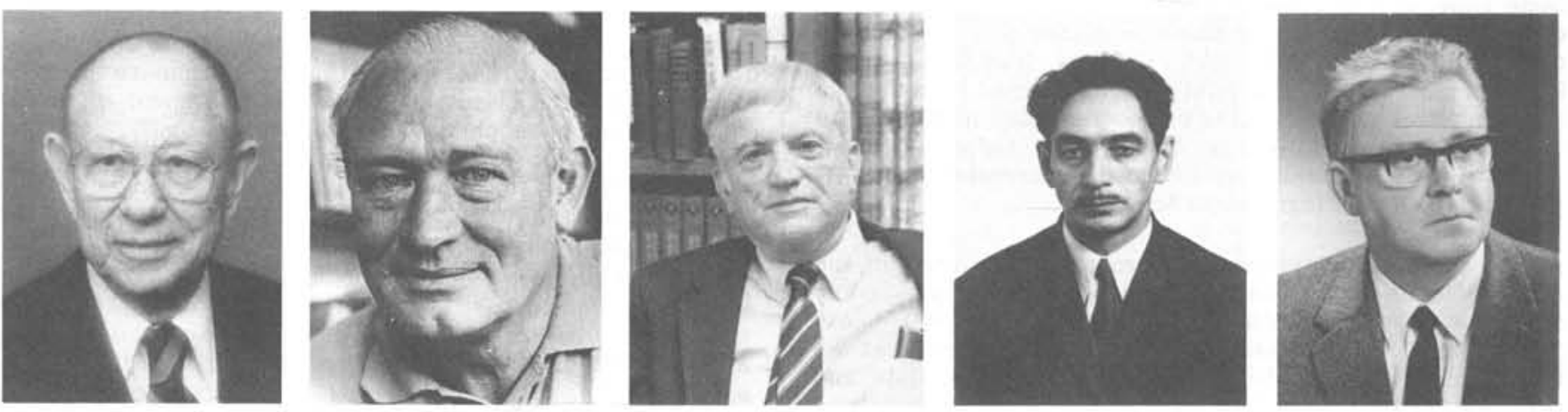

Figure 1: IAGC Presidents: left to right, $E$. Ingerson, L.H. Ahrens, G. Wetherill, V.L. Barsukov, M.H. Grunenfelder. See also Table 1 .

in 1953. The commission met oceasionally to discuss such items as the compilation and publication of geochemical data, the definition and standardization of terms, and the evaluation of published analytical data, and to find means of accelerating the international exchange of information and assisting in the translation of geochemical documerits. The commission also planned and conducted five international symposia in the decade 1953-1963. should not be loosened. K. Sugawara (Japan) agreed with Vinogradov, but noted that "geochemistry is really a boundary science acting as a bridge between chemistry, geophysies and the geological sciences; thus, any international body representing geochemistry must have a foothold in the fields of chemistry, geophysies and geology." This meeting ended with the formation of an "Ad Hoc Committee on Geochemical Problems," which was largely destined to continue coordination of geochemical activities in association with IUGG.

One month after the Helsinki meeting, the Twenty-First International Geological Congress met at Copenhagen, and IUGS itself was formally established (see Harrison, in 
TABLE 1

OFFICERS AND COUNCIL MEMBERS OF IAGC, 1967 - 1989

\begin{tabular}{|c|c|c|c|c|c|}
\hline IAGC Executive & $1967-1972^{*}$ & $1972-1977$ & $1977-1980$ & $1980-1984$ & $1984-1989$ \\
\hline \multicolumn{6}{|l|}{ OFFICERS } \\
\hline President & $\begin{array}{l}\text { E. Ingerson } \\
\text { U.S.A. }\end{array}$ & $\begin{array}{l}\text { L.H. Ahrens } \\
\text { South Africa }\end{array}$ & $\begin{array}{l}\text { G. Wetherill } \\
\text { U.S.A. }\end{array}$ & $\begin{array}{l}\text { V.L. Barsukav } \\
\text { U.S.S.R. }\end{array}$ & $\begin{array}{l}\text { M.H. Grunenfelder } \\
\text { Switzerland }\end{array}$ \\
\hline Vice-President & $\begin{array}{l}\text { L.H. Ahrens } \\
\text { South Africa }\end{array}$ & $\begin{array}{l}\text { W.V. Shcherbina } \\
\text { U.S.S.R. }\end{array}$ & $\begin{array}{l}\text { 3. Gonit } \\
\text { France }\end{array}$ & $\begin{array}{l}\text { M.H. Grunenfelder } \\
\text { Switzerland }\end{array}$ & $\begin{array}{l}\text { H. Wanke } \\
\text { F.R.G. }\end{array}$ \\
\hline Vice-President & $\begin{array}{l}\text { A.I. Tugarinov } \\
\text { U.S.S.R. }\end{array}$ & $\begin{array}{l}\text { K.H. Wedepoht } \\
\text { F.R.G. }\end{array}$ & $\begin{array}{l}\text { Z. Pacal } \\
\text { Czechoslovakia }\end{array}$ & $\begin{array}{l}\text { 8. Hitchon } \\
\text { Canada }\end{array}$ & - \\
\hline Secretary & $\begin{array}{l}\text { K. Sugawara } \\
\text { Japan }\end{array}$ & $\begin{array}{l}\text { K. Keil } \\
\text { U.S.A. }\end{array}$ & $\begin{array}{l}\text { G.M. Anderson } \\
\text { Cansda }\end{array}$ & $\begin{array}{l}\text { 5. Deutsch } \\
\text { Belgium }\end{array}$ & $\begin{array}{l}\text { B. Hitchon } \\
\text { Canada }\end{array}$ \\
\hline Treasurer & $\begin{array}{l}\text { J.F. Lovering } \\
\text { Australia }\end{array}$ & $\begin{array}{l}\text { J.F. Lovering } \\
\text { Australis }\end{array}$ & $\begin{array}{l}\text { R.A. Binns } \\
\text { Australia }\end{array}$ & $\begin{array}{l}\text { E.E. Angino } \\
\text { U.S.A. }\end{array}$ & $\begin{array}{l}\text { E.E. Angino } \\
\text { U.S.A. }\end{array}$ \\
\hline Past-President & - & $\begin{array}{l}\text { E. Ingerson } \\
\text { U.S.A. }\end{array}$ & $\begin{array}{l}\text { L.H. Ahrens } \\
\text { South Africa }\end{array}$ & $\begin{array}{l}\text { G. Wetherill } \\
\text { U.S.A. }\end{array}$ & $\begin{array}{l}\text { V.L. Barsukov } \\
\text { U.S.S.R. }\end{array}$ \\
\hline \multicolumn{6}{|c|}{ COUNCIL MEMBERS } \\
\hline & $\begin{array}{l}\text { B. Carnbel } \\
\text { Czechoslovakia }\end{array}$ & $\begin{array}{l}\text { G.M. Brown } \\
\text { U.K. }\end{array}$ & $\begin{array}{l}\text { G. Bardossy } \\
\text { Hungary }\end{array}$ & $\begin{array}{l}\text { L. Barnes } \\
\text { U.S.A. }\end{array}$ & $\begin{array}{l}\text { 1. Barnes: } \\
\text { U.S.A. }\end{array}$ \\
\hline & $\begin{array}{l}\text { A.G.W. Cameron } \\
\text { U.S.A. }\end{array}$ & $\begin{array}{l}\text { M. Ferrara } \\
\text { Italy }\end{array}$ & $\begin{array}{l}\text { D.S. Coornbs } \\
\text { New Zealand }\end{array}$ & $\begin{array}{l}\text { U. Cordani } \\
\text { Brazil }\end{array}$ & $\begin{array}{l}\text { M. Carapezza } \\
\text { Italy }\end{array}$ \\
\hline & $\begin{array}{l}\text { M. Fornaseri } \\
\text { Italy }\end{array}$ & $\begin{array}{l}\text { 3. Goni } \\
\text { France }\end{array}$ & $\begin{array}{l}\text { A. Erlank } \\
\text { South Africa }\end{array}$ & $\begin{array}{l}\text { H. Greenwood } \\
\text { Canada }\end{array}$ & $\begin{array}{l}\text { K. Kigoshi } \\
\text { Japan }\end{array}$ \\
\hline & $\begin{array}{l}\text { K.5. Heier } \\
\text { Norway }\end{array}$ & $\begin{array}{l}\text { D. Lal } \\
\text { India }\end{array}$ & $\begin{array}{l}\text { M. Frey } \\
\text { Switzerland }\end{array}$ & $\begin{array}{l}\text { L.N. Kogarko } \\
\text { U.S.S.R. }\end{array}$ & $\begin{array}{l}\text { L.N. Kogarko } \\
\text { U.S.S.R. }\end{array}$ \\
\hline & $\begin{array}{l}\text { M. Roubault } \\
\text { France }\end{array}$ & $\begin{array}{l}\text { D.M. Shaw } \\
\text { Canada }\end{array}$ & $\begin{array}{l}\text { W.S. Fyfe } \\
\text { Canada }\end{array}$ & $\begin{array}{l}\text { A. Masuda } \\
\text { Japan }\end{array}$ & $\begin{array}{l}\text { D. Lal } \\
\text { India }\end{array}$ \\
\hline & $\begin{array}{l}\text { R.C. Sinha } \\
\text { India }\end{array}$ & $\begin{array}{l}\text { K. Sugawara } \\
\text { Japan }\end{array}$ & $\begin{array}{l}\text { K.S. Heier } \\
\text { Norway }\end{array}$ & $\begin{array}{l}\text { Y. Tardy } \\
\text { France }\end{array}$ & $\begin{array}{l}\text { 5. Moorbath } \\
\text { U.K. }\end{array}$ \\
\hline & $\begin{array}{l}\text { E.A. Vincent E. } \\
\text { U.K. }\end{array}$ & $\begin{array}{l}\text { zadeozky-Kardoss } \\
\text { Hungary }\end{array}$ & $\begin{array}{l}\text { 1. Kushiro } \\
\text { Japan }\end{array}$ & $\begin{array}{l}\text { S.R. Taylor } \\
\text { Australia }\end{array}$ & $\begin{array}{l}\text { F. Mrna } \\
\text { Czechosiovakía }\end{array}$ \\
\hline & $\begin{array}{l}\text { K.H. Wedepohl } \\
\text { F.R.G. }\end{array}$ & $\begin{array}{l}\text { N.B. Vassoevich } \\
\text { U.S.S.R. }\end{array}$ & $\begin{array}{l}\text { 1.D. Ryabchikov } \\
\text { U.S.S.R. }\end{array}$ & $\begin{array}{l}\text { H. Wanke } \\
\text { F.R.G. }\end{array}$ & $\begin{array}{l}\text { H. Sorensen } \\
\text { Denmark }\end{array}$ \\
\hline \multicolumn{6}{|c|}{$\begin{array}{l}\text { During this period the Association executive included an Associate Secretary (R.M. Perhac, U.S.A.) and an } \\
\text { Associate Treasurer (Z. Pacal, Czechoslovakia). }\end{array}$} \\
\hline
\end{tabular}

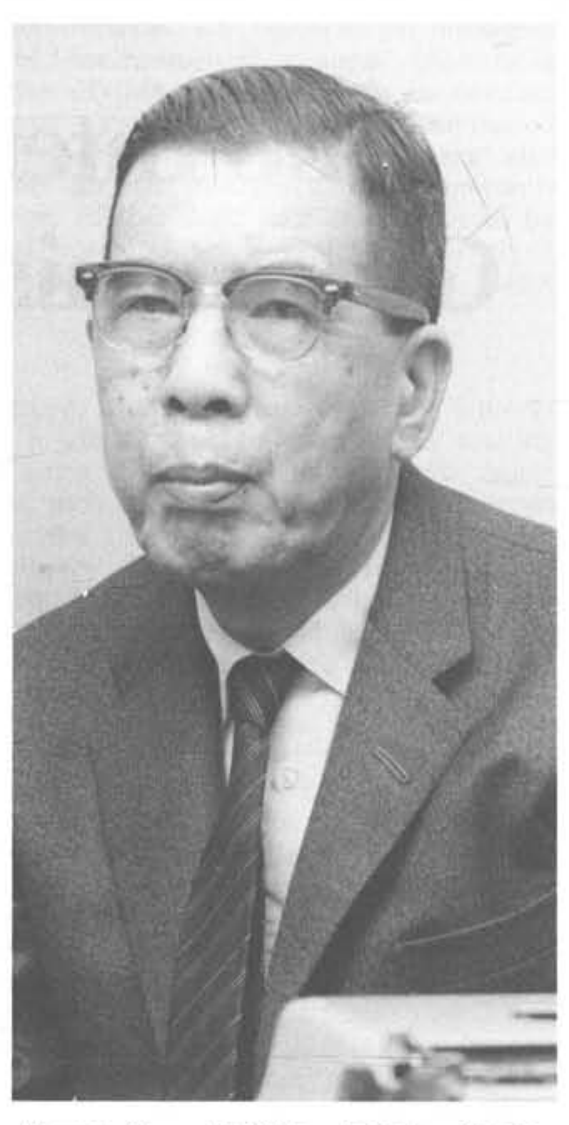

Figure 2: IAGC's first Secretary, K. Sugawara (Japan), a prime promoter of the interdisciplinary nature of geochemistry.
Episodes, March 1986). During the Congress, the IUPAC commission on geochemistry met once again. It included A.P. Vinogradov, E. Ingerson (U.S.A., Vice-Chairman) and L.H. Ahrens (South Africa, Secretary; see Fig. 1). At the same time, a joint meeting was held between the IUPAC commission, the IUGG ad hoc committee and a Congress committee, chaired by C.W. Correns (F.R.G.) and E. Ingerson (Secretary). The joint meeting agreed to set up an inter-union ad hoc committee of geochemistry to coordinate the geochemical activities among the three different unions. This new committee included K. Krauskopf (U.S.A.) as Chairman and E. Ingerson as Secretary.

Among the various geochemical groups in existence in the early 1960 s, the IUPAC commission continued to play a key role. However its meeting in London in July 1963, unexpectedly became its last. It was reported here that an independent Union of Geochemistry was not possible and that both IUPAC and ICSU had recommended against an inter-union organization for geochemistry. For the first time, geochemists presented a unified front in favour of the formation of a new, separate international organization of geochemistry. The commission reported to IUPAC its consensus that the primary association of geochemists should be with geologists (IUGS), but it expressed the hope that an active commission on geochemistry would continue to be maintained within IUPAC.

Later in the summer of 1963, at the IUGG meeting in Berkeley, a resolution was submitted to the General Assembly expressing "its desire to set up an International Association of Geochemistry within IUGG." The Assembly recognized the importance of geochemistry to several of its affiliated associations and encouraged them to make use of the appropriate parts of the science. However, IUGG did not wish to assume the responsibility for all of geochemistry, or to become the spokesman for all geochemists.

This situation led Earl Ingerson, as Chairman or Secretary of three of the geochemical groups, to devote himself to the hard and time-consuming task of gathering the opinions of world geochemists and attempting to formulate a basic document for the discussion of the establishment of a new international geochemical association. Finally, through negotiations with IUGS, the preparatory meeting for the establishment of the new association was arranged during the first General Assembly of IUGS in New Delhi in 1964, and Ingerson circulated an invitation to the members of the IGC, IUGG, IUPAC and ICSU committees on geochemistry to attend.

\section{The New Delhi Meeting}

Earl Ingerson was prevented by illness from presiding at the New Delhi meeting, and he asked K. Sugawara (Fig. 2) to transact the business on his behalf. In New Delhi Sugawara met J.M. Harrison (Canada) and T. Sorgenfrei (Denmark), respectively, President and Secretary General of IUGS, whose kind assistance made the meeting possible. The meeting was held on December 17 and was attended by 48 participants from 15 countries. Having outlined the general background and situation, and having expressed his preparedness to assist any proper person who might preside over the meeting, as is common in such situations Sugawara was nominated Chairman. Ingerson's provisional agenda envisaged a three-day program, but due to the short time allocated, only three major items could be considered. These were confirmation of the unanimity for the organization of an independent geochemical association, discussion 
of the statutes of the association and the appointment of a committee to draft them, and discussion of the problems of the affiliation of the association with various unions.

The question of the establishment of an independent geochemical association was settled almost unanimously and a committee to draft the statutes was organized. The first draft was to be forwarded to Ingerson to whom subsequent drafts and the nomination of temporary officers of the new association were also entrusted. During the discussion on the problem of affiliation with unions, Harrison pointed out the need for a truly international association and why it should be affiliated with a union. Both he and I. Hela (Finland, representing IUGG) stressed the importance of close liaison with IUGS and IUGG, regardless of the decisions taken. It was agreed to delay the decision of affiliation pending further comprehensive examination and discussion

\section{Paris Meeting}

In November 1965, Ingerson ealled a meeting in Paris to discuss progress in launching the new association. The name International Association of Geochemistry and Cosmochemistry was approved. The draft statutes were discussed and the basis for nomination of officers and other council members was established. The temporary officers and council members elected were E. Ingerson (President), L.H. Ahrens (Vice-President), K. Sugawara (Secretary), E.A. Vincent (U.K., Treasurer), and Councillors A.G. Cameron (U.S.A.), M. Fornaseri (Italy), J.F. Lovering (Australia), J. Roubault (France), R.C. Sinha (India), A.I. Tugarinov (U.S.S.R.) and K.H. Wedepohl (F.R.G.).

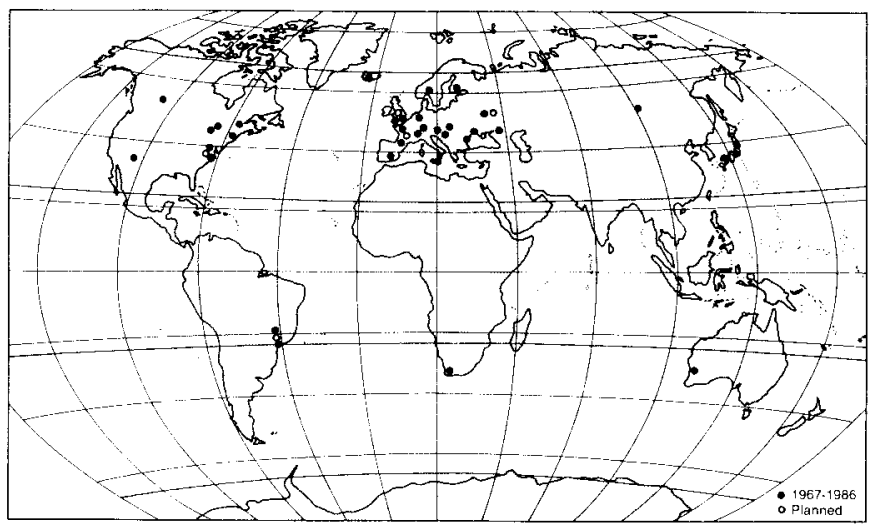

Figure 3: Distribution of IAGC-sponsored symposia.

Another important topic was the problem of the affiliation of IAGC with international unions. Being aware of the friendly attitude of IUGS towards the Association and the generous nature of the constitution of IUGS with respect to allowing the constituent associations a rather free hand in their activities, it was agreed to apply to IUGS for immediate affiliation.

To launch the Association, it was decided to organize the First International Symposium of Geochemistry and Cosmochemistry in Paris for September 1966. However, conflict with other meetings at Unesco headquarters made it necessary to postpone this symposium until May $8-11$, 1967, at which time IAGC was officially created and Council held its first regular meeting.

\section{First Council Meeting}

President Ingerson of ficially opened the meeting on May 8 , 1967, at Unesco headquarters in Paris. The ten Council members present are listed in Table 1, which also shows all officers and council members elected thereafter (see also Fig. 1). Observers at the Paris meeting were T.F.W. Barth

(Norway), representing IUGS, and M. Batisse (France), representing Unesco. Ways were discussed of publicizing the Association and its objectives, and particularly of obtaining the membership and participation of national geochemical organizations.

The financing of the new Association was discussed at length, and initial dues were set at $\$ 30.00$ US for $\mathrm{National}$ Members and $\$ 3.00$ US for individual members. With respect to the latter, individual membership in an international organization was unusual at that time, but proved to be a particularly perceptive move in view of the special individual member subscription rates to Applied Geochemistry nearly two decades later.

Because of the wide range of interests covered by the disciplines of geochemistry and cosmochemistry, and to encourage the activities of the new Association, the decision was made to create a number of specialized working groups. Indeed, the international activities of some of these groups have provided the main focus for and international exposure of the Association. Long-range plans were also made for symposia to be run in association with

\section{TABLE 2}

IAGC WORKING GROUP

\section{Chairman}

Geochemical Prospecting

Water-Rock Interaction

\section{from Pollution \\ Extraterrestrial Geochemistry \\ Weather, Sedimentary and Diagenetic Processes}

from Poters - Pratection

Thermodynamics of Natural Processes

Cooperation in Applied Geochemistry

Geochemistry of Health and Disease
Academician Lev V. Tauson Irkutsk Inst. of Geochemistry Irkutsk 33, U.S.S.R.

Dr. Hitoshi Sakai

Ocean Research Institute Takyo University Minamidai l-15-1, Nakano-ku Tokyo 164, Japan

Prof. A.M. Nikanarov Hydrochemical Institute Stachky Prospect, 198 Rostov-on-Don 344090 U.5.S.R.

Dr. Heinrich Wanke Max-Planck Inst. für Chemie Abteilung Kosmochemie Saarstrasse 23 (Postfach 3060) Mainz D-6500

F.R.G.

\section{Dr. Yves Tardy}

Institut de Geologie

Universite Louis Pasteur 1 , rue Blessig, Strasbourg 67 France

Dr. Igor L. Khodakovsky Vernadsky Inst. of Geochernistry $\&$ Analytical Chemistry Academy of Sciences of the U.S.S.R.

Kosygin Street 19

Moscow 117334 , U.S.S.R.

Dr. Juan Goni

Universidade de Sao Paulo Instituto de Geociencias Caixa Postal 20899

5 ao Paulo, Brazil

Dr. Iain Thornton Applied Geochemistry Research Group

Department of Geology Imperial College London SW7 2A2, England

- To be appointed - 


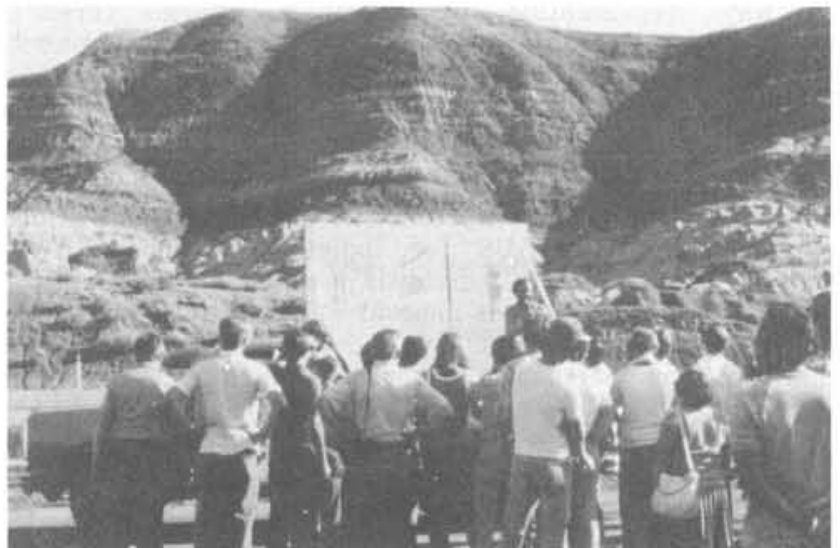

Figure 4: Examining coal depositional environments at the Drumheller Badlands of central Alberta, during the Third International Symposium on Water-Rock Interaction (July 1980).

activities of IUGS and Uneseo, both relationships proving mutually advantageous. Another link that was strengthened at that time and which was essential to the dissemination of scientific information by any international association was the decision to work with Pergamon Press Ltd. to publish the proceedings of the First International Symposium of Geochemistry and Cosmochemistry. The long association between IAGC and Pergamon eulminated recently with the first publication of Applied Geochemistry in 1986.

\section{International Symposia}

Throughout its nearly 20 years of existence and in fulfillment of one of its objectives to foster cooperation in and advancement of geochemistry and cosmochemistry, IAGC has sponsored or co-sponsored more than 40 international symposia worldwide (Fig. 3). Many of these have been organized jointly with national and international scientific organizations, governments and Unesco. Through the publication of the proceedings of many of these symposia IAGC achieves its second principle objective: sponsoring publications in geochemistry and cosmochemistry of a type not normally covered by existing organizations.

\section{Working Groups}

Although the records of IAGC show a plethora of commissions, and working, study, and interest groups, these were simplified under Presidents V.L. Barsukov and M.H. Grunenfelder to nine active working groups (Table 2). Their existence achieves the third principle objective of the Association: the study of problems that require, or would profit from, international cooperation. About half the symposia co-sponsored by IAGC are the direct result of the activities of the working groups (Figs, 4 and 5).

\section{Membership of the Association}

There are four classes of members, of which only the National Members are entitled to vote in the General Assembly; such a policy is consistent with the international associational status of IAGC. National Members include organizations such as committees, societies or academies designated by the Council of the Association as the official representative of the geochemists of their particular countries. National members currently include Australia, Canada, China, Czechoslovakia, East Germany, Finland, France, Hungary, Italy, Japan, The Netherlands, New Zealand, Norway, South Africa, Switzerland, Turkey, United Kingdom, U.S.A., U.S.S.R., West Germany and Zimbabwe.

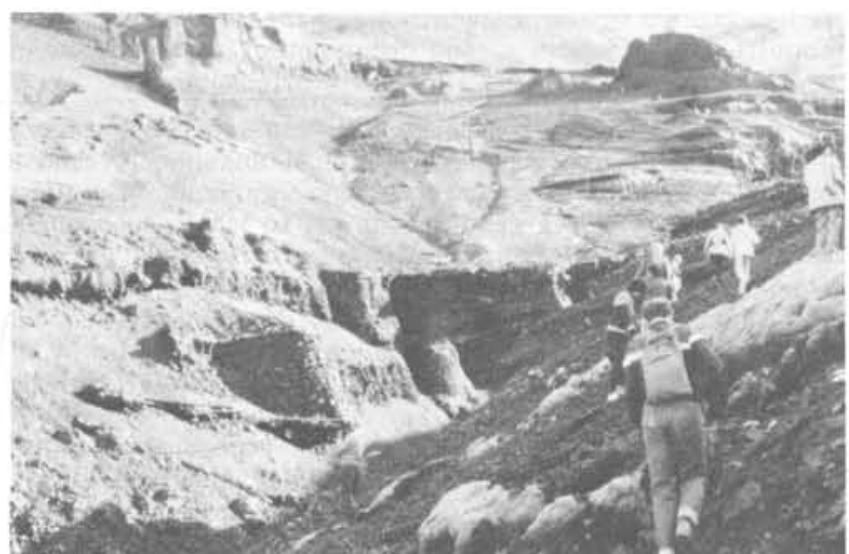

Figure 5: Trekking up a valley to examine pillow lavas and hyaloclastites during the IAVCEI/IAGC SCientific Assembly on the Generation of Major Basalt Types, Iceland, August 1982.

Unlike many international organizations, IAGC has provision for individual membership for anyone interested in geochemistry or cosmochemistry; currently there are nearly 530 individual members. There is also provision in the statutes for sustaining members although no individual or organization has applied. From time to time Council may nominate individuals as Honorary Fellows. Among those distinguished in this manner for their contributions to geochemistry or cosmochemistry have been Academician A.P. Vinogradov, Prof. T.F.W. Barth, Academician A.I. Tugarinov, the Association's first Secretary, Dr. K. Sugawara, and the first President, Prof. E. Ingerson to whom the first three issues of Applied Geochemistry are dedicated.

Special provision has also been made for international, regional, or national scientific societies, other than those designated as National Members, to be affiliated with IAGC as Associated Societies; the Geochemical Society has long been the only associated society.

\section{Internal Organization}

Final authority for the affairs of the Association rests with the General Assembly, which comprises delegates from the National Members, whose voting power is proportional to the number of geochemists represented within their individual countries. The General Assembly convenes during

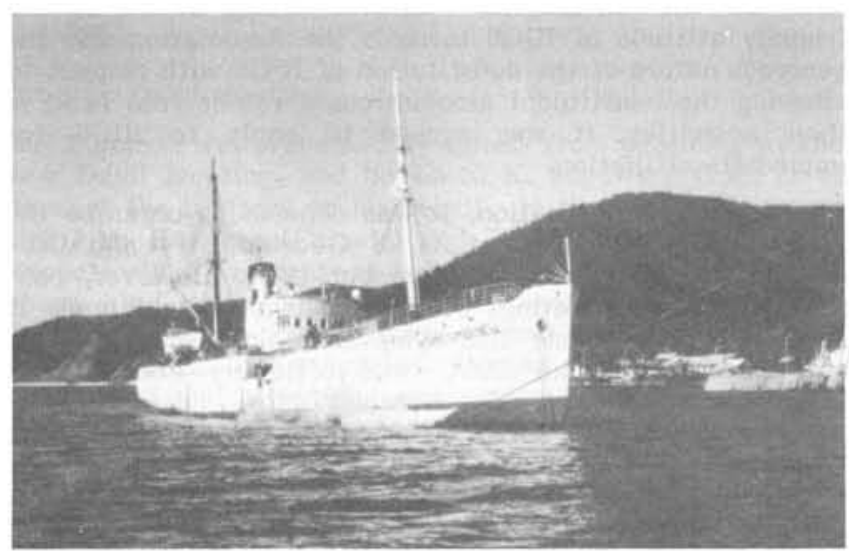

Figure 6: MV Komsomopetz, Lake Baikal, U.S.S.R., location of the IAGC Council meeting, September 1981 . 
meetings of the IGC, and may be attended by other members of the Association although they have no vote. Responsibility for supervising the activities, conducting the business, and achieving the objectives of the Association rests with the Council, which eurrently consists of the President, Vice-President, Secretary, Treasurer, PastPresident, and eight ordinary Council members.

During the presidencies of G. Wetherill, V.L. Barsukov and M.H. Grunenfelder (Fig. 1), the Council has met annually, usually at the same time as one of the symposia organized or co-sponsored by the Association. These meetings have taken place in a great variety of locations, ranging from a diesel ship on Lake Baikal (Fig. 6) to its latest meeting (1986) in the 'old music room' at St. John's College, Cambridge, England (Fig. 7). The nomination of officers and Council members is made through a Nominating Committee appointed by Council with the election being by majority vote of the General Assembly. In effect, the Council acts for the General Assembly between meetings of the latter.

The main income of the Association is derived from dues of the National Members and individual members, with major contributions from IUGS and Unesco. The major expenditures relate to support of symposia. In addition, the Association administers a bequest from Earl Ingerson, which supports the Earl Ingerson Distinguished Lecturship series.

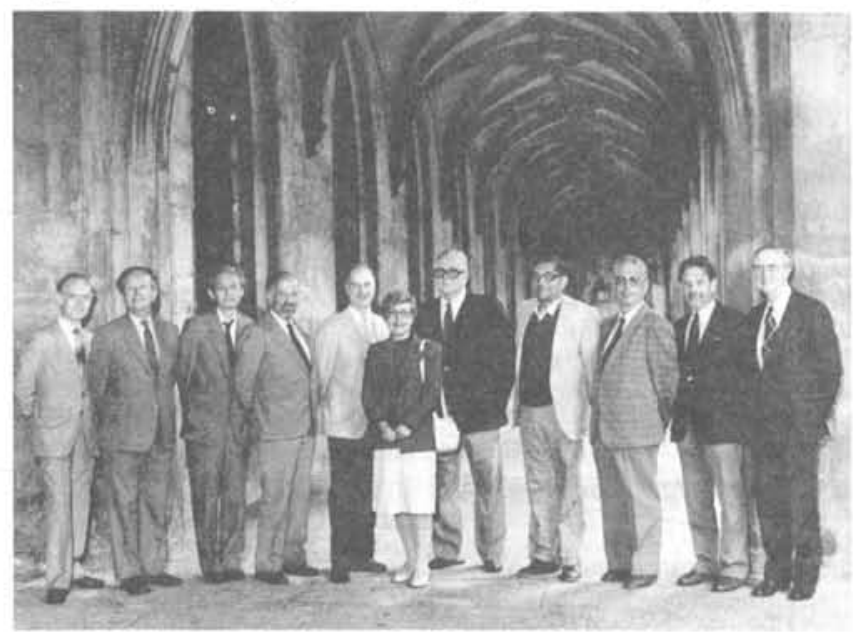

Figure 7: IAGC Council and representatives of the Royal Society meet at Cambridge, England, July 1986. Left to right - C.R. Argent (The Royal Society, U.K.); I. Thornton (Chairman, IAGC Working Group on Geochemistry of Health and Disease, U.K.); K. Kigoshi; S. Moorbath; B. Hitchon; L.N. Kogarko; M.H. Grunenfelder; D. Lal; H. Wanke; H. Sorensen, and P.A. Sabine (The Royal Society, U.K.). See also Table 1 .

\section{External Relations}

As an Affiliated Organization, IAGC reports to IUGS and, in turn, receives support and financial assistance. Over the years, the Association has cooperated with several other IUGS affiliates, most notably the Association of Exploration Geochemists, the Association Internationale pour l'Etude des Argiles, the International Association on the Genesis of Ore Deposits, the International Association of Hydrogeologists and the International Mineralogical Association.

Because IUGG provided an arena of discussion at a eritical time when the world geochemical community was seeking means of a formal international association, there has always been a special relationship between the Association and that body, but particularly with its affiliate IAVCEI, the International Association of Voleanology and Chemistry of the Earth's Interior.
IAGC has long been an associated organization of IUPAC and reports regularly on its activities to the Union's Assemblies. There is little doubt that it was the friendly framework provided by IUPAC that first gave geochemistry a truly international forum, from which IAGC finally emerged. Although some geochemists may still argue, even categorically, that geochemistry is one branch of chemistry, in truth, geochemistry is an interdisciplinary seience at the crossroads of chemistry, physies and the geological sciences.

\section{IAGC Today and Tomorrow}

Geochemistry is a young and developing science, of growing importance to all fields in the earth sciences as well as the environment and health. Newer instruments allow better definition of our terrestrial and cosmic environment. These factors can be seen in the changing emphasis of activities of the Association, with a distinct trend over the years from pure to applied geochemistry; the new journal Applied Geochemistry emphasizes this change in direction. Even the decennial Paris symposia of 1967,1977 , as well as that planned for 1987 to celebrate the 20th birthday of IAGC, show broad thematic changes from cosmochemistry to cosmochemistryplus-geochemistry to geochemistry, respectively.

Over the decades IAGC has cooperated with a growing number and variety of local, national and international organizations, some with very diverse objectives and subjects of study from geochemistry. This growing global acceptance of IAGC as the pre-eminent international geochemical organization confirms and supports the gradual changes in direction made over the years. The Association is about to begin its third decade with renewed vitality and sense of purpose. We welcome all to join the Association and to take an active part in its activities. Information on individual membership may be obtained from the author (address below).

\section{Acknowledgements}

This article was summarized from a more extensive historical review of the Association published in the first issue of Applied Geochemistry (vol. 1, 1986, p. 7-14). The writer thanks the Executive Editor of Applied Geochemistry for permission to reproduce considerable portions of the paper. J.P. Willis (Department of Geochemistry, University of Cape Town, South Africa) kindly sent the author the photograph of Prof. Ahrens, and K. Kigoshi (Gakushuin University, Japan) obtained the photograph of the late Prof. Sugawara.

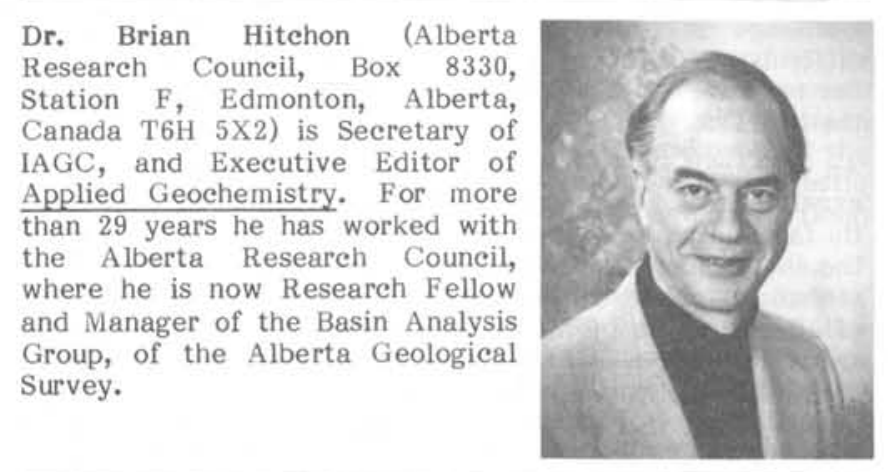

